\title{
Orchidaceae in an Atlantic Forest area: floristics and similarity to other Dense Ombrophilous Forest fragments
}

Marília Suzy Wängler ${ }^{1}$, Felipe Fajardo Villela Antolin Barberena ${ }^{2}$ and Rosana Conrado Lopes ${ }^{3}$

Received: November 11, 2013. Accepted: September 10, 2014

\begin{abstract}
The Brazilian Atlantic Forest is considered a global hotspot for biodiversity although it is currently threatened and highly fragmented. Orchidaceae in this phytogeographical domain is represented by 148 genera, of which 142 are endemic; Rio de Janeiro State contains approximately one third of all Brazilian orchid species. The Wildlife Protection Zone of the Palmares Environmental Protection Area (ZVS da APA Palmares) is located in the municipality of Paty do Alferes in Rio de Janeiro State and forms a mosaic of Dense Ombrophilous Forest fragments together with other conservation areas in the state. We surveyed Orchidaceae at 12 collection sites between July 2010 and February 2012 and analyzed floristic similarities between the collection sites and between 12 fragments of dense ombrophilous forest in Brazil utilizing PAST software and the Sørensen coefficient. The survey identified 27 genera and 43 species. Low indices of similarity among the areas were observed as well as weak support for grouping the ZVS da APA Palmares with the Serra da Tiririca Mountains. Greater conservation efforts are recommended for remnant fragments of Dense Ombrophilous Forest.
\end{abstract}

Keywords: Asparagales, Atlantic Forest, Conservation, Orchids, Taxonomy

\section{Introduction}

Orchidaceae is one of the largest botanical families and comprises approximately 25,000 species, corresponding to $6 \%-11 \%$ of all angiosperms (Ackerman 1998). This family has a cosmopolitan distribution, although most species occur in neotropical regions in humid forests and at medium altitudes (F Pinheiro et al. 2004). According to Barros et al. (2014), 2455 orchid species occur in Brazil, with 796 species distributed among 149 genera in the Atlantic Forest in Rio de Janeiro State.

The Atlantic Forest is perhaps the most threatened Brazilian biome and a global biodiversity hotspot. This once expansive forest is presently composed of small and mostly isolated remnant fragments $(<100 \mathrm{ha})$ in a secondary stage of growth (Metzger 2000; Metzger et al. 2009). Ribeiro et al. (2009) mapped 245,143 fragments of Atlantic Forest in Brazil, with the largest remnants being found in the Serra do Mar Range in the states of São Paulo, Rio de Janeiro, Paraná, and Santa Catarina.

Studies of the flora of Rio de Janeiro State contemplating the family Orchidaceae have largely been restricted to the following regions (CEPERJ 2013): the metropolitan region (including the municipalities of Rio de Janeiro, Duque de Caxias,
Itaboraí, Niterói, and São Gonçalo), Baixadas Litorâneas (Massambaba and Arraial do Cabo), Serrana (Cachoeira de Macacu, Guapimirim, Nova Friburgo, Teresópolis and Petrópolis), Costa Verde (Angra dos Reis and Mangaratiba), and Médio Paraíba (Itatiaia). The studies covered both inland and island areas, restinga (sandy, near-shore vegetation), rock outcrops, and fragments of Dense Ombrophilous Forest (Fagnani \& Siqueira 1992; Miller \& Warren 1996; Pinheiro 1999; Santana 2000; Mello 2003; Fraga et al. 2005; Saddi et al. 2005; Miller et al. 2006; Cunha \& Forzza 2007; Saddi 2008; Braga 2008; 2011; Barberena 2010; Faria 2010; Moreira 2010).

Other specific analyses of Orchidaceae richness and endemism have been presented by Chiron (2009) and Royer (2013). Regarding the spatial distribution of epiphytes to Orchidaceae, until now there have only been studies by Medeiros \& Jardim (2011).

Most studies have focused on the floristic composition and/or structure of epiphytes, and they have presented results that attribute great family representation and specific richness (Aguiar et al. 1981; Waechter 1986; Cervi et al. 1988; Dittrich et al. 1999; Kersten \& Silva 2001; 2002; Gonçalves \& Waechter 2002; Borgo \& Silva 2003; Giongo \& Waechter 2004; Cervi \& Borgo 2007; Kersten \& Kuniyoshi 2009; Geraldino et al. 2010; Bataghin et al. 2012).

\footnotetext{
${ }^{1}$ Instituto pé de planta (ONG), Rua Bruno Lucci 131, Vila Suiça, Miguel Pereira, RJ, 26900-000, Brazil

${ }^{2}$ Universidade Federal do Rio de Janeiro, Museu Nacional, Departamento de Botânica, Quinta da Boa Vista s/n, São Cristóvão, Rio de Janeiro, RJ 20940040, Brazil ${ }^{3}$ Universidade Federal do Rio de Janeiro, Instituto de Biologia, Departamento de Botânica, Laboratório Integrado de Sistemática Vegetal, R. Professor Rodolpho Paulo Rocco s/n, Rio de Janeiro, RJ 21941-490, Brazil

Author for correspondence: rosana@biologia.ufrj.br
} 
The Wildlife Protection Zone of the Palmares Environmental Protection Area (ZVS da APA Palmares) is located in the central southern region of Rio de Janeiro State, at the edge of the Serra do Mar Range. The Serra do Mar Range represents one of the largest continuous areas of Dense Ombrophilous Forest within the state and within the phytogeographical domain of the Atlantic Forest.

Due to the many gaps in our knowledge of Orchidaceae in Rio de Janeiro, the goal of this paper was to aid conservation efforts in remnant Atlantic Forest sites through a survey of the orchids in the ZVS da APA Palmares. We considered the associations between the state of regeneration of the areas and their species richness, endemism, spatial distributions of the epiphytes on the phorophytes, diversity analyses, and calculations of equitability, dominance, and similarity between the collection sites. In addition, we examined floristic similarities between 12 Dense Ombrophilous Forest areas in Brazil.

\section{Materials and methods}

\section{Study area}

The APA Palmares is located in Rio de Janeiro State in Southeast Brazil, in the municipality of Paty do Alferes $\left(22^{\circ} 15^{\prime}-22^{\circ} 28^{\prime} \mathrm{S}\right.$ and $\left.43^{\circ} 12^{\prime}-43^{\circ} 30^{\prime} \mathrm{W}\right)$, which borders the municipalities of Petrópolis, Miguel Pereira, Vassouras, and Paraíba do Sul. Only $13.8 \%$ of the municipality of Paty do Alferes is forested, and these areas are largely forest fragments in secondary or tertiary stages of growth and are commonly located in areas with steep topographies and scarps. The region has been used for agricultural purposes for more than 300 years and has participated in the economic cycles in Brazil, such as the production of sugarcane and coffee, the main activities responsible for regional deforestation (Dean 1996; Deister 2003).

The study area comprises approximately 178 ha and is largely situated at altitudes between 860 and $1177 \mathrm{~m}$. This areas is continuous with other conservation areas, including the Serra dos Órgãos National Park (PARNA Serra dos Órgãos) in Guapimirim, Magé, Petrópolis, Teresópolis, and the Petrópolis Environmental Protection Area and the Araras Biological Reserve in Petrópolis, the Santana Environmental Protection Area in Miguel Pereira, the Guandu Environmental Protection Area in Miguel Pereira, Paracambi, Piraí, Engenheiro Paulo de Frontin, Itaguaí, Seropédica, Nova Iguaçu, Japeri, Queimados, Vassouras, Rio Claro, and the Tinguá Biological Reserve (REBIO Tinguá) within the municipalities of Miguel Pereira and Petrópolis. All of these Units of Conservation constitute a mosaic of Dense Ombrophilous Forests (Fig. 1). The regional vegetation can be characterized as Dense Ombrophilous Montane Forest in secondary stages of regeneration (Veloso et al. 2012). The regional climate is temperate with a mean annual rainfall of $1200 \mathrm{~mm}$, and the rainiest trimester occurs between November and January (corresponding to approximately $50 \%$ of the total annual precipitation). The mean annual temperature is $20^{\circ} \mathrm{C}$, with June and July being the coldest months, and January and February the warmest (Cwa, according to the classification system of Köppen-Geiger). The abiotic data was provided by PESAGRO-RIO Estação Avelar, Paty do Alferes, located approximately $10 \mathrm{~km}$ from the APA Palmares.

\section{Systemization of the collections}

The ZVS da APA Palmares was divided into 12 subareas; hereafter referred to as A-L (Fig. 2). Each subarea was divided into $900 \mathrm{~m}^{2}$ sampling areas that were regrouped into 4500 $\mathrm{m}^{2}$ collection sites. Two collection sites in each subarea were subsequently chosen using the restricted randomization methodology (Greig-Smith 1983). The collection sites were laid out in the field using a GPS and tape measure and delimited using plastic tape. The collection sites were denominated A1-L1 for the first year, and A2-L2 for the second year, corresponding to a total of 24 sites. The collection sites were systematically covered to maximize the quantifications and observations of the target plants. Collections were made every two weeks for 19 months (July 2010 to February 2012), and 6\% of the total area of ZVS da APA Palmares was covered during 83 expeditions to the area. The orchids were located by visual searching with the aid of Nikula $20 \times 50$ binoculars, photodocumented using a Sony DSC H-50 digital camera, and georeferenced using a Garmin Map 76 CSX handheld GPS.

Species identifications - The specimens collected were prepared according to the usual botanical techniques (Fidalgo \& Bononi 1989) and subsequently deposited in the herbarium at the Federal University of Rio de Janeiro (RFA). The specimens were identified based on the specialized literature and comparisons with herbarium material. Sterile plants were collected and cultivated, and received identical preservation treatments after flowering.

Information was collected principally through field observations, although additional data was obtained from specimen labels in the GUA, HB, R, RB, RBR, RFA herbaria (Thiers 2014). The epiphytic species were classified according to Benzing (1990) as either true epiphytes, accidental epiphytes, facultative epiphytes, or hemiepiphytes (primary or secondary). The classifications of the other species were based on Pabst \& Dungs (1975).

The vegetation in the subareas was observed during field excursions, including the time spent defining the collection sites and during collections. The phorophytes were measured with a tape measure (whenever possible) in the regions where the epiphytes were encountered (circumference and distance above ground level), and their total heights were estimated.

\section{Spatial distributions of the epiphytes on the phorophytes}

These analyses were adapted from Kersten et al. (2009): lower trunk (up to $1.3 \mathrm{~m}$ above the ground), middle trunk, upper trunk (the upper $1.3 \mathrm{~m}$ ), internal canopy (above the 

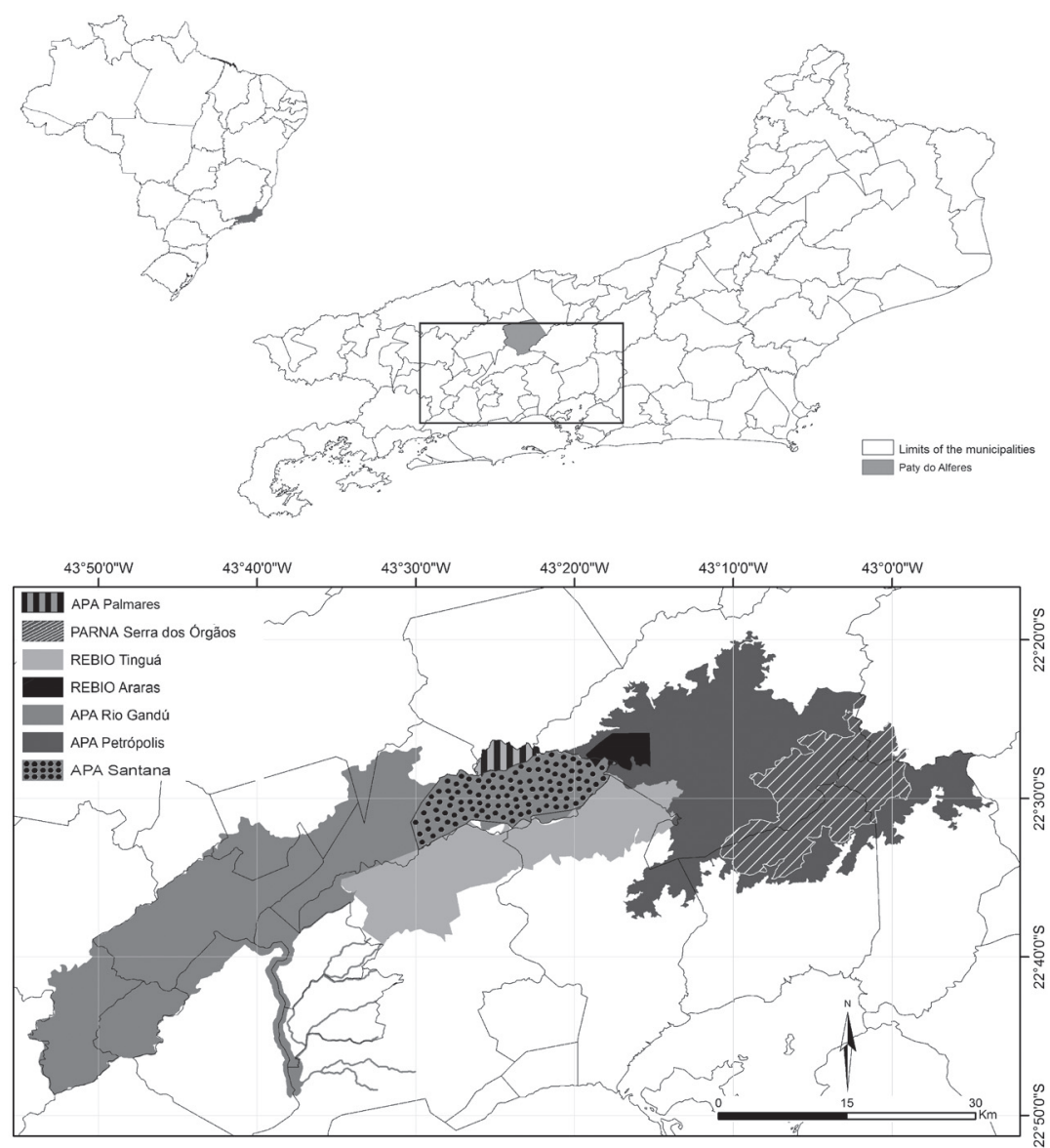

Figure 1. Localization of the Palmares Environmental Protection Area (APA Palmares) in the municipality of Paty do Alferes, as well as other Conservation Areas in Rio de Janeiro State, Brazil. APA Petrópolis=Petrópolis Environmental Protection Area; APA Rio Guandú=Guandú Environmental Protection Area; APA Santana=Santana Environmental Protection Area; Araras Biological Reserve=REBIO Araras; PARNA Serra dos Órgãos=Serra dos Órgãos National Park; REBIO Tinguá=Tinguá Biological Reserve.

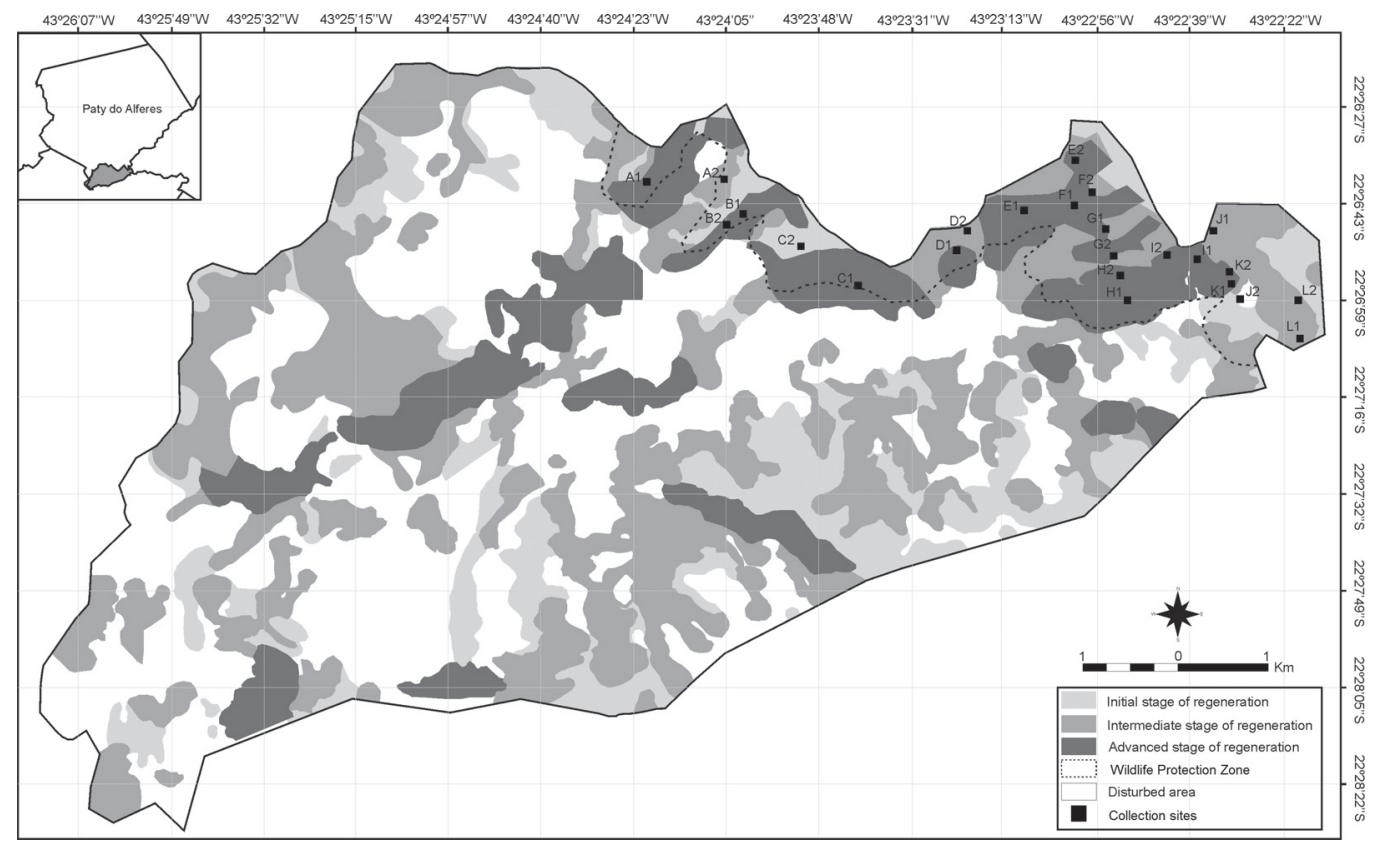

Figure 2. Localization of the APA Palmares in the municipality of Paty do Alferes, indicating the Wildlife Protection Zone (ZVS da APA Palmares) and the collection sites. 
first bifurcation, including the principal branches), and external canopy (terminal branches). In terms of the Cyatheaceae, the caudex was considered to represent the lower or middle trunk, and the insertion point of the fronds at the crown was considered the upper trunk.

\section{Richness analyses}

All of the individuals encountered were considered in these analyses. For Zygopetalum maculatum, we measured the numbers of individuals in $3 \mathrm{~m}^{2}$ and that value was extrapolated to the entire area occupied by the species. The quantifications of Zygopetalum maxillare considered the number of Cyatheaceae individuals colonized.

Floristic similarity and other statistical analyses - Based on the Shannon \& Weaver index (Pielou 1974), we also analyzed the diversity $\left(H^{\prime}\right)$, equitability $(E)$, and dominance (c) in each subarea.

Analyses of floristic similarity between the collection sites in the ZVS da APA Palmares were performed with PAST (Paleontological Statistics) software using Sørensen's similarity coefficient (Ss). This index was chosen as it lends greater weight to common species. A total of 5000 bootstrap replications were used to calculate internal support for the groupings. The areas were grouped using the UPGMA algorithm. We used the following bootstrap support categories according to Whitten et al. (2005): weak (50\%-74\%), moderate $(75 \%-84 \%)$, and strong $(85 \%-100 \%)$. Percentages below $50 \%$ were considered to reflect a lack of support. A presence (1) or absence (0) matrix of the species, including information from all of the collection sites, was constructed to analyze and interpret the data. Barros et al. (2014) was employed to verify synonyms. Taxa without a precise identification to the species level were excluded from the analyses.

Identical statistical treatments were applied to 12 areas of Dense Ombrophilous Forests located in Southeast Brazil (Ilha Grande State Park - PEIG; REBIO Tinguá; Guapiaçú Ecological Reserve - REGUA; Rio das Pedras Private Natural Reserve - RPPN Rio das Pedras; PARNA Serra dos Órgãos (FFVA Barberena pers. com.); Itatiaia National Park- PARNA Itatiaia; Serra da Tiririca State Park - PESET; Intervales State Park - PE Intervales; Santa Teresa; Serra Negra and Serra do Funil, and ZVS da APA Palmares) and southern regions of Brazil (Serra da Prata) in continental areas or on islands (JBRJ 2002; Pereira \& Ribeiro 2004; Saddi et al. 2005; Zipparro et al. 2005; Braga 2008; 2011; Barros 2008; Barberena 2010; Blum 2010; Abreu et al. 2011). The areas were considered to be largely covered by Dense Ombrophilous Forest based on the vegetation classifications presented by the authors of each publication in which species lists and vouchers were available.

\section{Results}

A total of 2478 individuals belonging to 27 genera and 43 species were encountered in the established collection sites. Of these, 22 species were exclusively terrestrial, 17 were true epiphytes, Catasetum cernuum was a facultative epiphyte, Vanilla organensis was a secondary hemiepiphyte, Cyclopogon iguapensis was rupiculous, and Zygopetalum maculatum was both terrestrial and rupiculous (Tab. 1).

Table 1. Subfamilies, tribes, subtribes, and species recorded in the Wildlife Protection Zone of the Palmares Environmental Protection Area, in Paty do Alferes, Rio de Janeiro State, Brazil, emphasizing the substrate (s), numbers of individuals recorded per species (i), numbers of collection sites in which they were encountered (p), species endemic to Brazil (e) are marked with an $\mathrm{x}$, their distribution by phytogeographical domains (pd), and the states in which they occur. (Substrate: $\mathrm{e}=\mathrm{epiphyte}$, $\mathrm{fe}=$ facultative epiphyte, $\mathrm{sh}=$ secondary hemiepiphyte, $\mathrm{r}=$ rupiculous and $\mathrm{t}=$ terrestrial; phytogeographical domains: $\mathrm{Am}=\mathrm{Amazonian} ; \mathrm{Ca}=\mathrm{Caatinga} ; \mathrm{Ce}=\mathrm{Cerrado}$ and $\mathrm{AF}=$ Atlantic Forest; abbreviations of the states: Alagoas (AL), Amazonas (AM), Amapá (AP), Bahia (BA), Ceará (CE), Distrito Federal (DF), Espírito Santo (ES), Goiás (GO), Maranhão (MA), Mato Grosso (MT), Mato Grosso do Sul (MS), Minas Gerais (MG), Pará (PA), Paraíba (PB), Paraná (PR), Pernambuco (PE), Rio de Janeiro (RJ), Rio Grande do Sul (RS), Roraima (RR), Santa Catarina (SC), São Paulo (SP), Sergipe (SE), Tocantins (TO).

\begin{tabular}{|c|c|c|c|c|c|c|c|c|c|}
\hline Subfamily & Tribe & Subtribe & Species & $\mathbf{s}$ & $\mathbf{i}$ & $\mathbf{p}$ & $\mathbf{e}$ & pd & Distribution in Brazil \\
\hline \multirow[t]{3}{*}{ Vanilloideae } & Pogoniieae & & Cleistes libonii (Rchb.f.) Schltr. & $\mathrm{t}$ & 6 & 3 & $\mathrm{x}$ & $\mathrm{AF}$ & BA MG RJ SP PR SC \\
\hline & & & Pogoniopsis schenckii Cogn. & $\mathrm{t}$ & 62 & 1 & $\mathrm{x}$ & $\mathrm{AF} \mathrm{Ce}$ & PE MG RJ SP PR \\
\hline & Vanillineae & & Vanilla organensis Rolfe & sh & 1 & 1 & $\mathrm{x}$ & $\mathrm{AF}$ & MT RJ SP \\
\hline \multirow[t]{9}{*}{ Orchidoideae } & Cranichideae & Goodyerinae & Aspidogyne argentea (Vell.) Garay & $\mathrm{t}$ & 3 & 1 & & $\mathrm{AF} \mathrm{Ce}$ & BA ES RJ SP PR SC RS \\
\hline & & & Aspidogyne hylibates (Rchb.f.) Garay & $\mathrm{t}$ & 112 & 4 & $\mathrm{x}$ & $\mathrm{AF}$ & RJ MG SP \\
\hline & & Spiranthinae & Cyclopogon congestus (Vell.) Hoehne & $\mathrm{t}$ & 28 & 7 & & $\mathrm{AF}$ & RJ SP PR SC RS \\
\hline & & & Cyclopogon graciliscapus Schltr. & $\mathrm{t} / \mathrm{r}$ & 5 & 3 & & $\mathrm{AF} \mathrm{Ce}$ & DF MG RJ SP PR \\
\hline & & & Cyclopogon iguapensis Schltr. & $\mathrm{r}$ & 1 & 1 & $\mathrm{x}$ & $\mathrm{AF}$ & RJ SP PR SC \\
\hline & & & Cyclopogon variegatus Barb.Rodr. & $\mathrm{t}$ & 6 & 2 & & $\mathrm{AF}$ & RJ SP PR SC \\
\hline & & & Eltroplectris triloba (Lindl.) Pabst & $\mathrm{t}$ & 5 & 3 & & $\mathrm{AFCa}$ & BA ES RJ SP \\
\hline & & & $\begin{array}{l}\text { Eurystyles actinosophila (Barb.Rodr.) } \\
\text { Schltr. }\end{array}$ & $\mathrm{e}$ & 461 & 14 & & $\mathrm{AFCe}$ & MG RJ SP PR \\
\hline & & & Pteroglossa glazioviana (Cogn.) Garay & $\mathrm{t}$ & 141 & 7 & & $\mathrm{AF}$ & PA MG ES RJ SP PR \\
\hline
\end{tabular}


Table 1. Continuation.

\begin{tabular}{|c|c|c|c|c|c|c|c|c|c|}
\hline Subfamily & Tribe & Subtribe & Species & s & i & $\mathbf{p}$ & e & pd & Distribution in Brazil \\
\hline & & & Sacoila lanceolata (Aubl.) Garay & $\mathrm{t}$ & 42 & 7 & & $\mathrm{AF} \mathrm{Ca} \mathrm{Ce}$ & $\begin{array}{l}\text { AM AP PA AL BA PB PE SE } \\
\text { DF GO MT MG ES RJ SP PR } \\
\text { SC RS }\end{array}$ \\
\hline & & & Sauroglossum nitidum (Vell.) Schltr. & $\mathrm{t}$ & 301 & 20 & & $\mathrm{AF} \mathrm{Ca} C \mathrm{e}$ & BA DF RJ SP PR RS \\
\hline & & Cranichidinae & $\begin{array}{l}\text { Prescottia plantaginifolia Lindl. ex } \\
\text { Hook. }\end{array}$ & $\mathrm{t}$ & 1 & 1 & $\mathrm{x}$ & $\mathrm{AFCe}$ & $\begin{array}{l}\text { AL PB PE SE BA GO MG ES } \\
\text { RJ SP PR SC }\end{array}$ \\
\hline & & & Prescottia stachyodes (Sw.) Lindl. & $\mathrm{t}$ & 7 & 4 & & $\mathrm{AF} \mathrm{Ca} C e$ & $\begin{array}{l}\text { AM PA AL BA CE PB PE DF } \\
\text { MG ES RJ SP PR SC RS }\end{array}$ \\
\hline & Orchideae & Orchidinae & Habenaria josephensis Barb.Rodr. & $\mathrm{t}$ & 46 & 8 & $\mathrm{x}$ & $\mathrm{AF}$ & $\begin{array}{l}\text { AL PA PE SE BA MG ES RJ SP } \\
\text { PR SC RS }\end{array}$ \\
\hline & & & Habenaria parviflora Lindl. & $\mathrm{t}$ & 40 & 1 & & $\mathrm{AF} \mathrm{Ca} C e$ & $\begin{array}{l}\text { RR BA SE DF GO MG ES RJ } \\
\text { SP PR SC RS }\end{array}$ \\
\hline & & & Habenaria petalodes Lindl. & $\mathrm{t}$ & 3 & 2 & & $\begin{array}{l}\mathrm{AF} \mathrm{Am} \mathrm{Ca} \\
\mathrm{Ce}\end{array}$ & $\begin{array}{l}\text { PA AL BA PE PA SE DF MS } \\
\text { GO MG ES RJ SP }\end{array}$ \\
\hline & & & Habenaria rodeiensis Barb.Rodr. & $\mathrm{t}$ & 1 & 1 & $\mathrm{x}$ & $\mathrm{AFCe}$ & $\begin{array}{l}\text { BA DF GO MG ES RJ SP } \\
\text { PR SC }\end{array}$ \\
\hline & & & Habenaria aff. rupicola Barb.Rodr. & $\mathrm{t}$ & 1 & 1 & & $\mathrm{AFCe}$ & AP DF GO MT MG SP SC RS \\
\hline \multirow[t]{22}{*}{ Epidendroideae } & Cymbidieae & Catasetinae & Catasetum cernuum (Lindl.) Rchb.f. & fe & 53 & 11 & $\mathrm{x}$ & $\mathrm{AF} C e$ & MG ES RJ SP SC RS \\
\hline & & & Grobya amherstiae Lindl. & e & 58 & 14 & $\mathrm{x}$ & $\mathrm{AFCe}$ & BA MG ES RJ SP PR SC \\
\hline & & Eulophiinae & Oeceoclades maculata (Lindl.) Lindl. & $\mathrm{t}$ & 158 & 10 & & $\begin{array}{l}\mathrm{AF} \mathrm{Am} \mathrm{Ca} \\
\mathrm{Ce}\end{array}$ & All states less AP \\
\hline & & Oncidiinae & $\begin{array}{l}\text { Baptistonia cruciata (Rchb.f.) } \\
\text { V.P.Castro \& Chiron }\end{array}$ & e & 35 & 5 & $\mathrm{x}$ & $\mathrm{AF}$ & RJ ES SP \\
\hline & & & $\begin{array}{l}\text { Baptistonia truncata (Rchb.f.) Chiron } \\
\text { \& V.P.Castro }\end{array}$ & $\mathrm{e}$ & 2 & 2 & $\mathrm{x}$ & $\mathrm{AF}$ & RJ ES SP MG \\
\hline & & & $\begin{array}{l}\text { Brasilidium praetextum (Rchb.f.) } \\
\text { Campacci }\end{array}$ & $\mathrm{e}$ & 58 & 13 & $\mathrm{x}$ & $\mathrm{AF}$ & BA ES RJ SP PR \\
\hline & & & Gomesa laxiflora (Lindl.) Rchb.f. & e & 30 & 3 & $\mathrm{x}$ & $\mathrm{AF}$ & ES RJ SP PR SC \\
\hline & & & Gomesa recurva R.Br. & e & 188 & 10 & & $\mathrm{AFCe}$ & MG ES RJ SP PR SC \\
\hline & & Maxillariinae & Bifrenaria tetragona (Lindl.) Schltr. & e & 1 & 1 & $\mathrm{x}$ & $\mathrm{AF}$ & RJ SP PR SC RS \\
\hline & & Zygopetalinae & Dichaea cogniauxiana Schltr. & e & 3 & 1 & $\mathrm{x}$ & $\mathrm{AFCe}$ & BA MT MG ES RJ SP PR SC RS \\
\hline & & & Dichaea pendula (Aubl.) Cogn. & $\mathrm{e}$ & 3 & 1 & & AF Am & AM RR ES RJ SP PR SC RS \\
\hline & & & $\begin{array}{l}\text { Zygopetalum maculatum (Kunth) } \\
\text { Garay }\end{array}$ & $\mathrm{t} / \mathrm{r}$ & 404 & 3 & & $\mathrm{AF} \mathrm{Ca} C \mathrm{C}$ & BA MG ES RJ SP PR SC RS \\
\hline & & & Zygopetalum maxillare Lodd. & $\mathrm{e}$ & 56 & 4 & & $\mathrm{AFCe}$ & $\begin{array}{l}\text { BA MT MG ES RJ SP PR } \\
\text { SC RS }\end{array}$ \\
\hline & Tropidieae & & Corymborkis flava (Sw.) Kuntze & $\mathrm{t}$ & 1 & 1 & & $\mathrm{AF}$ & RJ SP PR SC RS \\
\hline & Epidendreae & Laeliinae & Epidendrum ecostatum Pabst & e & 3 & 2 & & $\mathrm{AF}$ & RJ SP PR SC \\
\hline & & & Epidendrum filicaule Lindl. & $\mathrm{e}$ & 12 & 2 & $\mathrm{x}$ & $\mathrm{AF}$ & BA MG ES RJ SP \\
\hline & & & $\begin{array}{l}\text { Epidendrum pseudodifforme Hoehne } \\
\text { \& Schltr. }\end{array}$ & e & 6 & 3 & $\mathrm{x}$ & $\mathrm{AF}$ & MG RJ SP SC RS \\
\hline & & & Epidendrum secundum Jacq. & $\mathrm{t}$ & 10 & 1 & & $\begin{array}{l}\mathrm{AF} \mathrm{Am} \mathrm{Ca} \\
\mathrm{Ce}\end{array}$ & $\begin{array}{l}\text { AM AP PA RR TO AL BA CE } \\
\text { PA PE SE DF GO MT MG RJ } \\
\text { SP PR SC RS }\end{array}$ \\
\hline & Calypsoeae & & Govenia utriculata (Sw.) Lindl. & $\mathrm{t}$ & 91 & 5 & & $\mathrm{AFCe}$ & DF MG RJ SP PR SC RS \\
\hline & Vandeae & Polystachyinae & Polystachya estrellensis Rchb.f. & e & 13 & 2 & $\mathrm{x}$ & $\underset{\mathrm{Ce}}{\mathrm{AF} \mathrm{Am} \mathrm{Ca}}$ & $\begin{array}{l}\text { AM AP PA RR AL BA PB } \\
\text { PE SE DF GO MG RJ SP PR } \\
\text { SC RS }\end{array}$ \\
\hline & & Angraecinae & Campylocentrum spannagelii Hoehne & e & 2 & 1 & $\mathrm{x}$ & $\mathrm{AF}$ & RJ \\
\hline & Triphoreae & & Psilochilus modestus Barb.Rodr. & $\mathrm{t}$ & 18 & 2 & $\mathrm{x}$ & $\mathrm{AF} A m$ & AM MG ES RJ SP PR SC RS \\
\hline
\end{tabular}


Of the four subfamilies found in Brazil, we encountered representatives of Vanilloideae ( 3 spp.) and Orchidoideae (18 spp.), both with species essentially terrestrial or hemiepiphytic, and Epidendroideae (22 spp.) comprised species that were predominantly epiphytic (Tab. 1).

Among the species recorded, Aspidogyne hylibates, Baptistonia cruciata, and Baptistonia truncata are endemic to the Atlantic Forest and only occur in Southeast Brazil; Campylocentrum spannagelii was the only species that occurred only in Rio de Janeiro State. Most of the species (93\%) are known to be widely distributed and occur in other geographical regions of Brazil, sometimes with neotropical or even transcontinental distributions, such as Polystachya estrellensis and Oeceoclades maculata that occur in the Americas, Asia, and Africa.

The collection sites included an enormous heterogeneity of habitats, predominantly due to agricultural activities underway in the ZVS da APA Palmares. All of the established collection sites contained invasive species and/or were in agricultural areas, thus forming vegetation mosaics (Fig. 3) that included monocultures of Araucaria angustifolia (Bertol.) Kuntze ("araucária" trees), Eucalyptus sp. (eucalyptus), Croton sp. ("capinxigui"), and Prunus persica (L.) Batsch (peaches). The study area also contained abandoned properties, with the presence of Pteridium arachnoideum (Kaulf.) Maxon. ("samambaião"), Imperata brasiliensis Trin. ("sapê"), Bambusa spp. (bamboo), Guadua sp. ("bambuzinho"), and Scleria pterota Presl. (cut-grass), as well as pastures planted with Brachiaria sp. ("capim-braquiária"). The crest line that limits the ZVS da APA Palmares to the north stretches for approximately $3 \mathrm{~km}$, although only $120 \mathrm{~m}$ of that extension holds forest vegetation.
Analysis of the distributions of the epiphytes on the phorophytes demonstrated that Baptistonia truncata, Dichaea cogniauxiana, D. pendula, Epidendrum ecostatum, E. pseudodifforme, and Polystachya estrellensis were exclusively found in the internal canopy; Campylocentrum spannagelii was found growing only in the middle trunk, and B. tetragona only on the lower trunk; while Brasilidium praetextum, Catasetum cernuum, and Gomesa recurva were encountered in all of the phorophyte zones (although with greater frequency in the internal canopy for the first two species and at middle trunk level for the latter) (Fig. 4). The species Brasilidium praetextum (5.7\%), Catasetum cernuum (14.8\%), Epidendrum filicaule (12.5\%), and Gomesa recurva (14.4\%) were also observed growing in soil.

Floristic richness varied from five species in subarea $\mathrm{K}$ to 17 species in subareas J and L (Fig. 5). The mean richness value was approximately 12 species per subarea. Fourteen species occurred in only a single collection site. Collection site B1 had the largest number of species (14). Subarea B had the greatest diversity index $\left(\mathrm{H}^{\prime}=0.883082\right)$, reflecting its high equitability and richness values (16 spp.); subareas J and L demonstrated the greatest species richness. Approximately $95 \%$ of the vegetation in subarea B was native, with trees up to $20 \mathrm{~m}$ tall and high levels of humidity. Subarea $\mathrm{K}$ had the highest equitability value $(e=0.901779)$, although the lowest species richness (5 spp.).

The low spatial heterogeneity of subarea $\mathrm{K}$ was related to its small number of available niches. The greatest dominance index was seen in subarea $\mathrm{E}(\mathrm{c}=2.889803)$ due to a dense population of Zygopetalum maculatum that occupied approximately $200 \mathrm{~m}^{2}$ and contained an estimated 400 individuals.

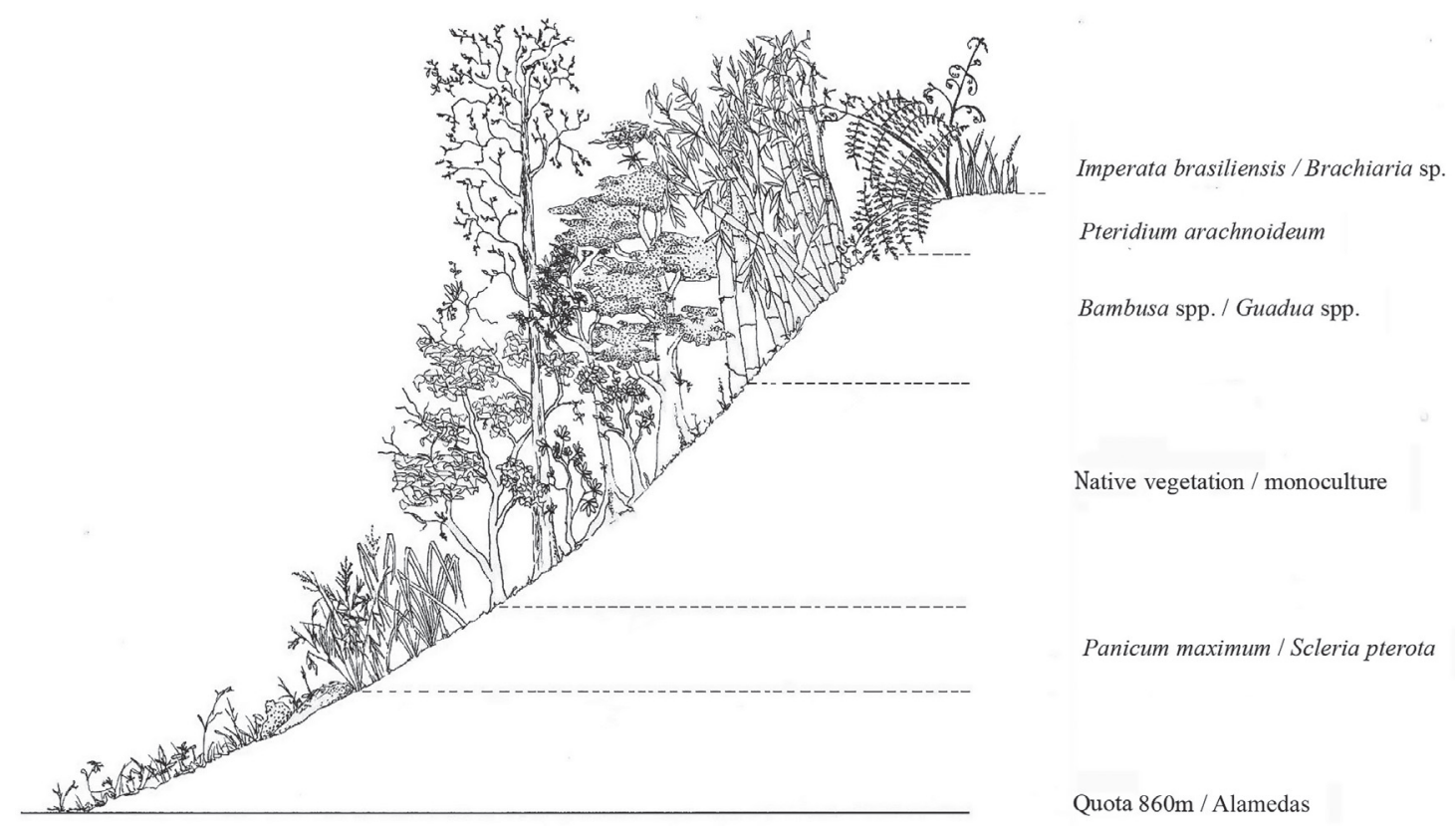

Figure 3. Schematic profile of the vegetation encountered in the Wildlife Protection Zone of the Palmares Environmental Protection Area between the lowest elevation (860 m or Alameda) and the mountain peaks, in Paty do Alferes, Rio de Janeiro State, Brazil. 


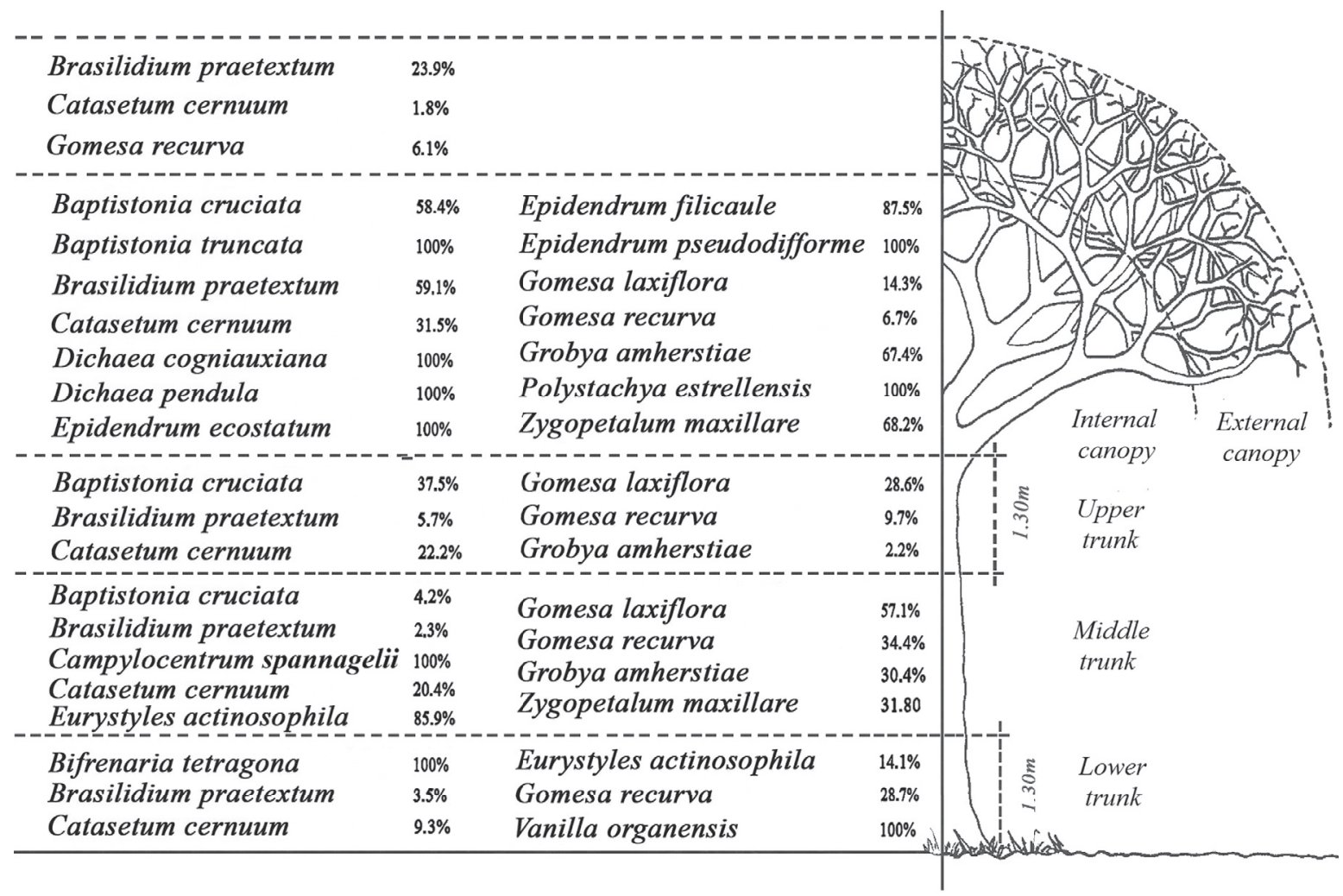

Figure 4. Spatial disposition of the epiphytes in phorophytes in the Wildlife Protection Zone of the Palmares Environmental Protection Area, in Paty do Alferes, Rio de Janeiro State, Brazil. Adapted from Kersten \& Waechter (2011).

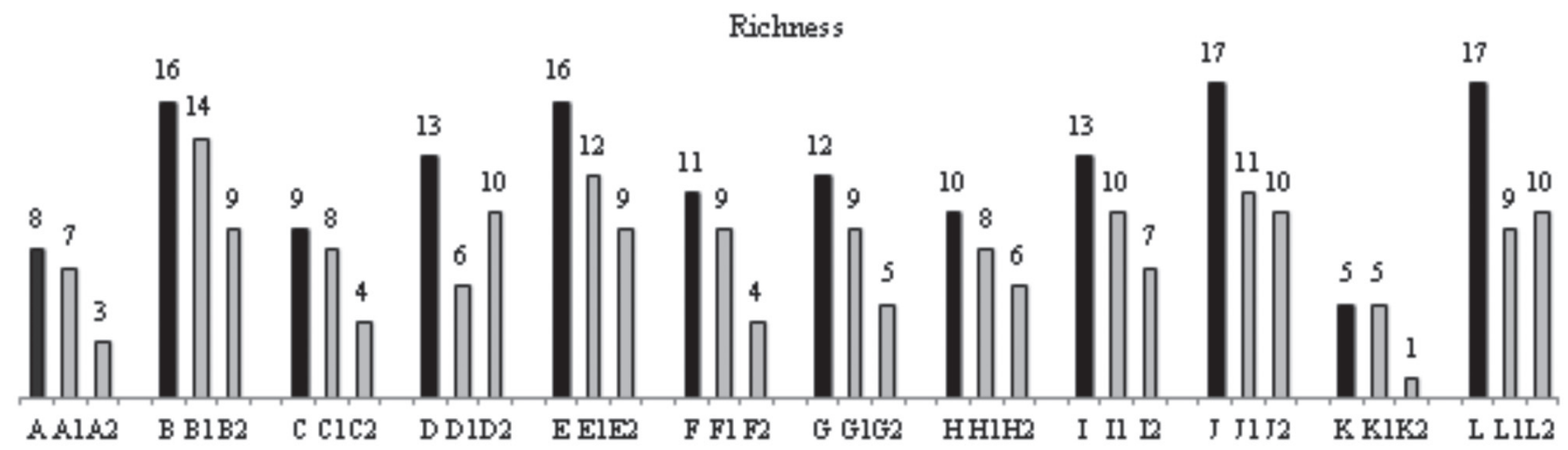

Figure 5. Species richness encountered in the areas (A-L) and collection sites (A1-L2) in the Wildlife Protection Zone of the Palmares Environmental Protection Area, in Paty do Alferes, Rio de Janeiro State, Brazil.

The dendrogram generated from the similarity analyses of the collection sites (Fig. 6) indicated three groupings with weak bootstrap support between B1-G1 (65\%), B2$\mathrm{H} 2(54 \%)$, and $\mathrm{J} 2-\mathrm{L} 2(66 \%)$. All of the other groupings demonstrated values below $50 \%$, indicating the absence of support as groupings did not occur in most of the trees that were generated. Therefore, the greatest similarity index was $\mathrm{Ss}=0.8$ between collection sites $\mathrm{B} 2$ and $\mathrm{H} 2$ that had six species in common: Brasilidium praetextum, Eurystyles actinosophila, Gomesa recurva, Govenia utriculata, Grobya amherstiae, and Sauroglossum nitidum. Due to the small numbers of species at some collection sites, the similarities between many collection sites was quite low, including values of zero, thus generating groupings with weak or no internal support.

In relation to the areas of Dense Ombrophilous Forest investigated here, low floristic similarities (below 50\%) were found between all of them (Fig. 7). However, two large groups were formed ( $86 \%$ of the resampling): the first group included PEIG, REBIO Tinguá, REGUA, RPPN Rio 


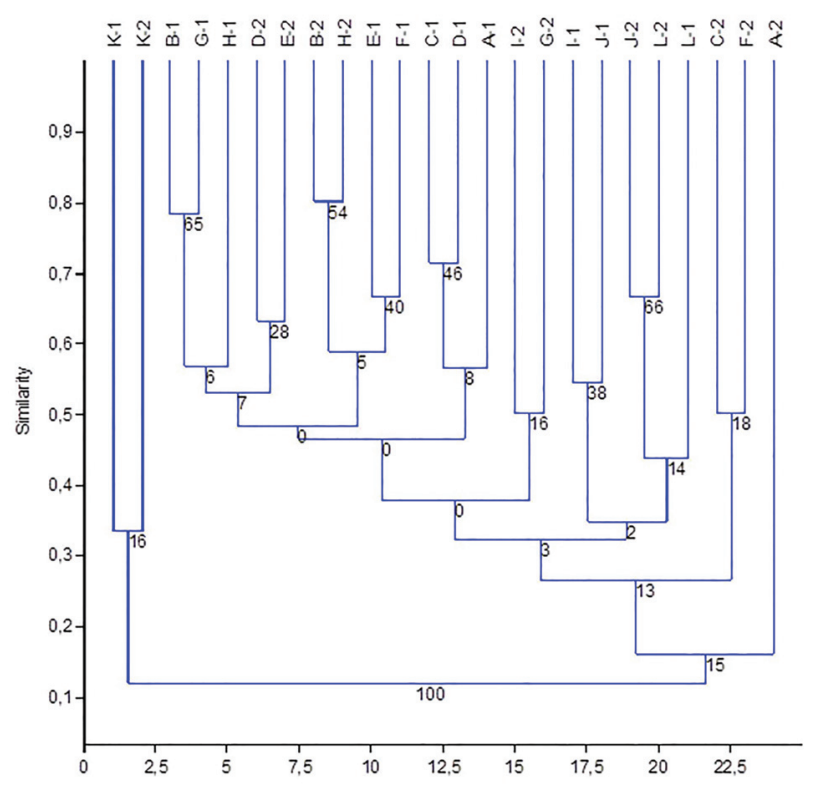

Figure 6. Dendrogram demonstrating the floristic similarities of the 24 collection sites in the Wildlife Protection Zone of the Palmares Environmental Protection Area, in Paty do Alferes, Rio de Janeiro State, Brazil, based on Sørensen's index and the UPGMA algorithm, with 5000 bootstrap replications. Cophenetic Correlation Coefficient $=0.7768$. A1-L1 correspond to collection sites surveyed in the first study year, and A2-L2 to collection sites surveyed in the second year.

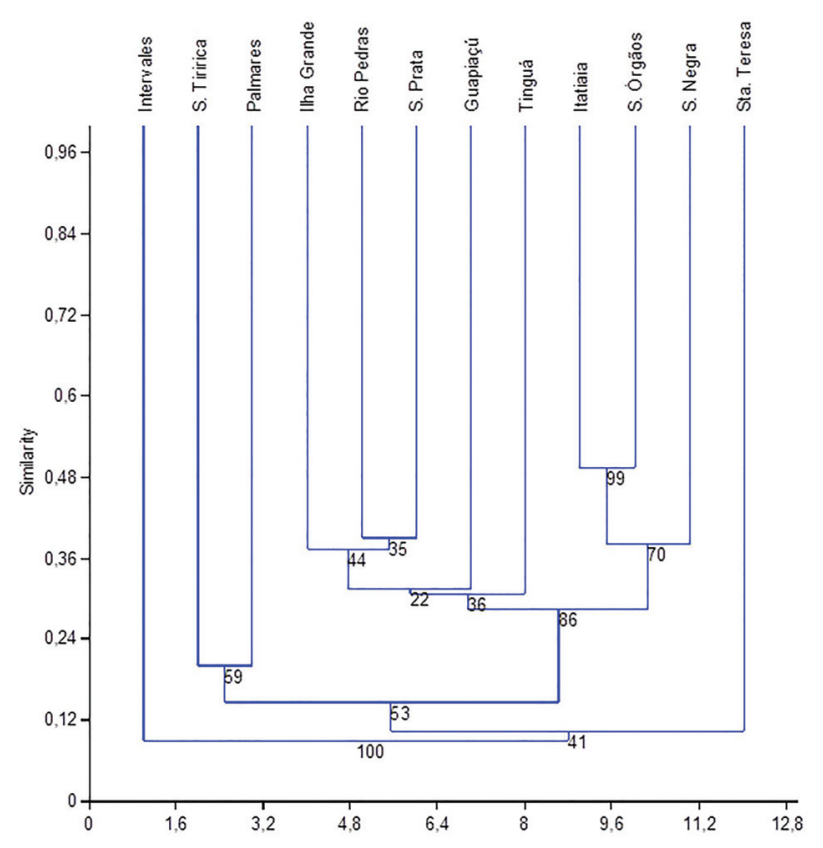

Figure 7. Dendrogram demonstrating the floristic similarities of the Orchidaceae in 12 areas of Dense Ombrophilous Forest, based on Sørensen's index and the UPGMA algorithm, with 5000 bootstrap replications. Cophenetic Correlation Coefficient=0.9046. Guapiaçú=Guapiaçú Ecological Reserve; Ilha Grande=Ilha Grande State Park; Intervales = Intervales State Park; Itatiaia=Itatiaia National Park; Palmares=Wildlife Preservation Zone at Palmares; Rio das Pedras=Rio das Pedras Private Natural Reserve; S. Negra=Serra Negra and Serra do Funil; S. Órgãos=Serra dos Órgãos National Park; S. Prata=Serra da Prata; S. Tiririca=Serra da Tiririca State Park; Sta Teresa=Santa Teresa; and Tinguá=Tinguá Biological Reserve. das Pedras, and Serra da Prata; the second group included PARNA Itatiaia, PARNA Serra dos Órgãos, Serra Negra and Serra do Funil. The greatest floristic similarity was observed between PARNA Itatiaia and PARNA Serra dos Órgãos ( 49\%), with strong bootstrap support (99\%). The ZVS da APA Palmares demonstrated very low similarity with any of the other areas (less than 20\%) and grouped with only weak support (59\%) with PESET. PE Intervales and Santa Teresa did not group with any other areas.

\section{Discussion}

Orchidaceae and Bromeliaceae are the most abundant epiphytes in the Atlantic Forest biome, and colonize approximately $80 \%$ of the trees, with high humidity and low light levels being the primary factors determining their establishment and development (Benzing 1990). Although an epiphytic lifestyle restricts vegetative development, it does favor seed dispersal and exposure to pollinator vectors (Tonhasca Jr. 2005). According to Budowski (1965), colonization by grasses, shrubs, vines, and some trees is favored in degraded environments and/or during the initial successional stages of regeneration as generalist pollinators are better represented than specialists. The portions between these two pollinator classes will change as regeneration proceeds, and guilds will be reestablished as floristic composition progresses (Pereira \& Ribeiro 2004). Epiphytes are usually encountered in large numbers in secondary recovery stages due to secondary tree growth, although with low richness (Kersten et al. 2009). The numbers of species in the ZVS da APA Palmares varied in relation to the arboreal-shrub structure, which was greater in collection sites with larger phorophytes and/or lower light levels and in the presence of water resources and steep topographies, indicating that these factors facilitate the establishment of species more susceptible to adverse abiotic regimes.

Orchidaceae consistently stand out in epiphyte surveys, and often represent more than $30 \%$ of the species encountered (Kersten et al. 2009). Their percentages in the ZVS da APA Palmares varied in terms of the regeneration states of the various collection sites and as a function of intense harvesting of orchid species by amateur and professional collectors (which could be verified by visiting local residences and illegal markets). Dead individuals of the subtribe Pleurothallidinae, which comprises more than 3000 species and is consistently well-represented in epiphyte surveys (Pridgeon 1982), were only found in one of the collection sites. This is probably due to the intensive extraction occurring in the locality. In many localities of the municipality, we observed trunks for sale containing many specimens belonging to the subtribe Pleurothallidinae. Gomesa recurva was encountered in both well-preserved and open areas in the ZVS da APA Palmares, indicating its wide amplitude of ecological tolerance. Notwithstanding this trait, the species is known to be present at sites at an advanced stage of regeneration (or on remnant 
old-growth trees) due to its late colonization of potential epiphytic environments, and is observed only at sites with closed and stratified canopies (Kersten et al. 2009).

The vertical dispositions of the epiphytes on phorophytes varied in accordance with the abiotic necessities of each species (Fig. 4). The canopy offers greater luminosity, and the branches are horizontal and more amenable to humus accumulation. The apex of the trunk, at the first bifurcation receives protection from the canopy in terms of amenable luminosity and humidity levels, and it can hold propagules originating from the canopy above it. The vertical position of the median portion of the trunk facilitates water and nutrient runoff, making propagule establishment and growth more difficult by diminishing local humidity. The lower portion of the trunk, near the soil, is a more humid and favorable microhabitat that often harbors accidental epiphytes (Nieder et al. 2001; Kersten \& Waechter 2011). Most of the epiphytes in the ZVS da APA Palmares colonized the internal canopy, with its greater availability of humidity and nutrients. Because water availability is one of the most relevant limiting factors to the growth of epiphytic floras (Zotz \& Hietz 2001), the thickest and oldest horizontal branches that are protected from the direct effects of wind and strong illumination are the most propitious to their growth. The second most populous grouping of epiphytic species was concentrated in the median portions of trunks, suggesting that these species are less dependent on water but require greater luminosity (Fig. 4).

The numbers of terrestrial orchid species in the ZVS da APA Palmares are higher compared to epiphytes, although their quantification may have been underestimated due to the difficulty of observing individuals because of their small size and/or isolated placement and, because they are leafless during anthesis (Rocha \& Waechter 2006). According to Menini Neto et al. (2007), Pogoniopsis schenkii is considered rare or threatened due to habitat destruction, although insufficient collection efforts may also influence its apparent low frequency. According to Rocha \& Waechter (2006), Sacoila lanceolata can be found in anthropogenically altered environments due to its robust nature, and it will germinate in pastures very quickly after burning. Habenaria is the largest genus of terrestrial orchids in Brazil, with approximately 170 species, and is generally encountered on poor soils (Batista et al. 2004; Rocha \& Waechter 2006; Abreu \& Menini Neto 2010). The results of the present study corroborated these earlier results. Forest fragmentation affects populations and communities, altering the dynamics of their dependent floras and faunas. The surrounding altered matrices and historical disturbances may interfere with the dissemination of seeds and propagules and alter their relationships with critical biological phenomena (Viana \& Pinheiro 1998). Edge effects, in the specific case of the ZVS da APA Palmares, are apparent at mountaintops, along roadways, near residences, and at contacts with monocultures. Mountaintops are often characterized by an abundance of $P$. arachnoideum (Fig. 3), which can tolerate highly weathered soils containing high levels of toxic metals such as aluminum (EFM Pinheiro et al. 2004).

After burning, the first invasive species encountered is Panicum maximum Jacq., followed by $P$. arachnoideum. The former tolerates burning very well due to stocks of carbohydrates in their long subterranean rhizomes and the production of large numbers of buds that allow rapid occupation of degraded areas (Silva Matos \& Belinato 2010). The dense layers of biomass derived from their dry leaves inhibit the germination and/or establishment of the seeds of other pioneer species through allelopathic interactions, shading, and/or by acting as a barrier to reaching the soil surface (Silva Matos \& Belinato 2010). In the collection sites where Pteridium sp. occupied a large percentage of the surface area (K1 and F2), the orchid species encountered were terrestrial and resistant to burning, such as $S$. lanceolata, $H$. rupicola, and $H$. rodeiensis, which were observed sprouting in recently burned soils.

The high numbers of epiphytic species encountered on the ground while still attached to fallen branches may be related to the successional stage of the vegetation, and we observed many individuals of Piptadenia gonoacantha (Mart.) J.F.Macbr. This species is classified as a pioneer or secondary initial that shows rapid development and a relatively short life cycle (Budowski 1965; Ferreira et al. 2001). Successional processes are initiated after deforestation occurs and, if the disturbances cease, the area can return to a near-original mature forest state (Gomes et al. 2004). As part of this process, the seedlings of $P$. gonoacantha, for example, remain quiescent in shaded environments until (natural or anthropogenic) openings occur, when they initiate full development.

Infestation by native bamboo species generally occur in the ZVS da APA Palmares where there has been commercial tree harvesting, and openings formed by this cutting favor their development and occupation. This observation corroborates data presented by Gomes et al. (2004), who compared two distinct areas: one that had experienced commercial tree harvesting and one that remained intact; the latter was found to have no significant bamboo infestation. The best preserved collection sites in the ZVS da APA Palmares showed very low percentages of bamboo infestation, with some of them being the result of planting by local residents, with much smaller fractions of native species.

Although the vegetation in the ZVS da APA Palmares is highly fragmented and currently in varying stages of regeneration, we noted that the two collection sites that demonstrated the highest similarity indices (B2 and H2) had similar phytophysiognomies, with approximately $90 \%-95 \%$ of native vegetation and no monoculture sites, and also with records of epiphytes.

Despite showing only weak internal support, the grouping of I1, J1, J2, L2, and L1 comprised collection sites located in the eastern region of the ZVS da APA Palmares with simi- 
lar characteristics; particularly more inclined topographies, less anthropogenic interference (fewer residences), upper canopies $>20 \mathrm{~m}$, and greater epiphyte richness (Fig. 2). Gomesa recurva was encountered at all five collection sites.

Although collection sites $\mathrm{K} 1$ and $\mathrm{K} 2$ demonstrated a low species similarity index $(\mathrm{IJ}=0.33)$, having only Sacoila lanceolata in common, they were grouped together because they are both areas with Brachiaria sp. pasture and were therefore distinct from the other collection sites. The low bootstrap values observed in the dendrogram (Fig. 6) for the other groupings can be directly related to vegetation heterogeneity among the collection sites, or are associated with the low number of species in each area.

Abreu et al. (2011) undertook analyses of the floristic similarities of Orchidaceae in 29 field and forest areas in Brazil, and their results grouped areas occurring in the same biome. However, these authors focused the discussion on campo rupestre vegetation (open, rocky fields), and included only two of the twelve Dense Ombrophilous Forest fragments examined in the present study (PARNA Itatiaia and PE Intervales). These same authors also demonstrated that geographical distances did not significantly influence floristic similarities among Orchidaceae. We attribute the low similarity values obtained in the present study to: (1) high habitat heterogeneity, resulting in only small numbers of shared species; or (2) the different sampling efforts and methodologies applied in each of the considered floristic surveys.

Our results indicated the difficulty of grouping areas of Dense Ombrophilous Forest. The weak bootstrap support (59\%) between the ZVS da APA Palmares and PESET, associated with their low similarity, was likewise related to the high heterogeneity of the habitats in the two regions. The ZVS da APA Palmares is an area undergoing forest regeneration, and there are a number of localities where the canopy is discontinuous and the sites are significantly altered, thus favoring the occurrence of terrestrial orchid species. The PESET holds extensive areas of Submontane Ombrophilous Forest that favor the occurrence of epiphytic species, as well as fragments of restinga (sandy, shoreline vegetation) and mangrove swamps. In general, the species most common in these two conservation areas are welldistributed throughout Brazil and occur in a number of phytogeographical domains.

As most of the groupings do not demonstrate significant bootstrap support, the true floristic relationships between them cannot yet be considered as clarified. The unexpected grouping of RPPN Rio das Pedras (RJ) and Serra da Prata $(\mathrm{PR})$ is an example of this methodological discrepancy, as the survey undertaken in the latter area was not exclusive to Orchidaceae. On the other hand, PARNA Itatiaia and PARNA Serra dos Órgãos demonstrated ample altitudinal variation and many similar phytophysiognomies, including altitudinal fields, in which systematic collections of Orchidaceae have been undertaken over many decades, justifying the elevated support seen for their grouping (99\%). It is also interesting to note that the PE Intervales plot did not group with any of the others, corroborating earlier observations (Abreu et al. 2011). The weak internal support observed for groupings of Atlantic Forest areas was not repeated with other vegetation types, as areas of campo rupestre influenced by either Caatinga or Cerrado vegetation demonstrated significant mutual floristic similarities (Abreu et al. 2011).

The present study revealed the necessity for standardizing floristic surveys. These surveys should be undertaken on a regular basis during all months of the year to include the flowering of the maximum number of species present, as many genera of Orchidaceae are difficult to identify in their vegetative phase. More intensive research in areas of Dense Ombrophilous Forest in Rio de Janeiro State and the conservation of remnant forest fragments will be indispensable to improve our understanding of the floristic relationships between them and to preserve the species richness of Orchidaceae.

\section{Acknowledgments}

The authors would like to thank the following: administration of the municipality of Paty do Alferes, particularly the Secretary of the Environment and the Municipal Environmental Police, for their logistical support; the team of "Estudos Botânicos na APA Palmares" program, including Alessandra Paiva, Danielle Massunaga, Fernanda Alzer, Giselle Mazzoni, Natália Fortuna, Renata Albuquerque, Robson Leonardo, and Ursula Costa, for their help with the field work; Vitor Ferreira for his assistance in establishing the methodology for the statistical analyses; our colleagues at the Laboratório Integrado de Sistemática Vegetal (LISV) da UFRJ; and Roy Funch for reviewing the English version of this manuscript.

\section{References}

Abreu NL, Menini Neto, L. 2010. As subfamílias Vanilloideae e Orchidoideae (Orchidaceae) em um fragmento da Serra da Mantiqueira, Minas Gerais, Brasil. Boletim Botânico da Universidade de São Paulo 28: 15-33.

Abreu NL, Menini Neto L, Konno TUP. 2011. Orchidaceae das Serras Negra e do Funil, Rio Preto, Minas Gerais, e similaridade florística entre formações campestres e florestais do Brasil. Acta Botanica Brasilica 25: 58-70.

Ackerman JD. 1998. Evolutionary potential in orchids: patterns and strategy for conservation. Selbyana 19: 8-14.

Aguiar LW, Citadini-Zanette V, Martau L, Backes A. 1981. Composição florística de epífitos vasculares numa área localizada nos municípios de Montenegro e Triunfo, RS, Brasil. Iheringia 28: 55-93.

Barberena FFVA. 2010. Orchidaceae no Parque Nacional do Itatiaia, Sudeste do Brasil: listagem e estudos taxonômicos na subtribo Laeliinae. Msc Thesis, Instituto de Pesquisas Jardim Botânico do Rio de Janeiro, Brazil.

Barros AAM. 2008. Análise florística e estrutural do Parque Estadual da Serra da Tiririca, Niterói e Maricá, RJ, Brasil. PhD Thesis, Instituto de Pesquisas Jardim Botânico do Rio de Janeiro, Brazil. 
Barros F, Vinhos F, Rodrigues VT, et al. 2014. Orchidaceae in Lista de Espécies da Flora do Brasil. Jardim Botânico do Rio de Janeiro. http:// floradobrasil.jbrj.gov.br/jabot/floradobrasil/FB179. 22 Aug. 2014.

Bataghin FA, Muller A, Pires JSR, Barros F, Fushita AT, Scariot EC. 2012. Riqueza e estratificação vertical de epífitas vasculares na Estação Ecológica de Jataí - área de Cerrado no Sudeste do Brasil. Hoehnea 39: 615-626.

Batista JAN, Bianchetti LB, Nogueira RE, Pellizzaroi KF, Ferreira FE. 2004. The genus Habenaria (Orchidaceae) in Itacolomi State Park, Minas Gerais, Brasil, Sitientibus. Série Ciências Biológicas 4: 25-36.

Benzing DH. 1990. Vascular epiphytes. General Biology and related biota. Cambridge, Cambridge University Press.

Blum CT. 2010. Os componentes epifítico vascular e herbáceo terrícola da Floresta Ombrófila Densa ao longo de um gradiente altitudinal na Serra da Prata, Paraná. PhD Thesis, Universidade Federal do Paraná, Brazil.

Borgo M, Silva SM. 2003. Epífitos vasculares em fragmentos de floresta mista, Curitiba, Paraná, Brasil. Revista Brasileira de Botânica 26: 391-401.

Braga MRA. 2008. Orquidófilos trabalhando para a conservação da Mata Atlântica. Orquidário 22: 19-29.

Braga MRA. 2011. A riqueza da nossa flora. Orquidário 25: 125-132.

Budowski G. 1965. Distribution of tropical American rain forest species in the light of sucessional processes. Turrialba 15: 40-42.

CEPERJ - Fundação Centro Estadual de Estatísticas, Pesquisas e Formação de Servidores Públicos do Rio de Janeiro. 2013. Estado do Rio de Janeiro, regiões de Governo. http://www.ceperj.rj.gov.br/ceep/ info_territorios/divis_regional.html. 7 Sep. 2013.

Cervi AC, Acra LA, Rodrigues L, Train S, Ivan-Chechen SL, Moreira ALOR. 1988. Contribuição ao conhecimento das epífitas (exclusive Bromeliaceae) de uma floresta de Araucária no Primeiro Planalto Paranaense. Insula 18: 75-82.

Cervi AC, Borgo SM. 2007. Epífitos vasculares no Parque Nacional do Iguaçu, Paraná (Brasil). Levantamento preliminar. Fontqueria 55: 415-422.

Chiron GR. 2009. Riqueza e endemismo de espécies de Baptistonia (Orchidaceae), no Brasil. Hoehnea 36: 459-477.

Cunha MFB, Forzza RC. 2007. Orchidaceae no Parque Natural Municipal da Prainha, RJ, Brasil. Acta Botanica Brasilica 21: 383-400.

Dean W. 1996. A ferro e fogo: a história e a devastação da Mata Atlântica Brasileira. São Paulo, Companhia das letras.

Deister S. 2003. Serra do Tinguá - 300 Anos de conquistas. Do século XVII ao século XX. Miguel Pereira, Dedalus Informática Ltda.

Dittrich VAO, Kozera C, Silva SM. 1999. Levantamento florístico dos epífitos vasculares do Parque Barigui, Curitiba, Paraná, Brasil. Iheringia 52: 11-21.

Fagnani MPK, Siqueira CIS. 1992. Orquídeas da Restinga de Massambaba. Orquidário 6: 51-54.

Faria CC. 2010. Variação na riqueza de espécies de orquídea em um gradiente altitudinal na Serra dos Órgãos, RJ. Msc Thesis, Universidade Federal do Rio de Janeiro, Brazil.

Ferreira JN, Ribeiro JF, Lazarini da Fonseca JC. 2001. Crescimento inicial de Piptadenia gonoacantha (Leguminosae, Mimosoideae) sob inundação em diferentes níveis de luminosidade. Revista Brasileira de Botânica 24: 561-566.

Fidalgo O, Bononi VLR. 1989. Técnicas de coleta, preservação e herborização de material botânico. São Paulo, Instituto de Botânica.

Fraga CN, Kollman LJC, Menezes LFT. 2005. Orchidaceae na Restinga de Marambaia, Rio de Janeiro, RJ. In: Menezes LFT, Peixoto AL, Araujo DSD. (eds.). História Natural da Marambaia. Seropédica, EDUR Editora da Universidade Rural. p. 121-132.

Geraldino HCL, Caxambú MG, Souza DC. 2010. Composição florística e estrutura da comunidade de epífitas vasculares em uma área de ecótono em Campo Mourão, PR, Brasil. Acta Botanica Brasilica 24: 469-482.
Giongo C, Waechter JL. 2004. Composição florística e estrutura comunitária de epífitos vasculares em uma floresta de galeria na Depressão Central do Rio Grande do Sul. Revista Brasileira de Botânica 27: 563-572.

Gomes APC, Souza AL, Meira Neto JAA. 2004. Alteração estrutural de uma área florestal explorada convencionalmente na bacia do Paraíba do Sul, Minas Gerais, nos domínios de Floresta Atlântica. Revista Árvore 28: 407-417.

Gonçalves CN, Waechter JL. 2002. Epífitos vasculares sobre espécimes de Ficus organensis isolados no norte da planície costeira do Rio Grande do Sul: padrões de abundância e distribuição. Acta Botanica Brasilica 16: 429-441.

Greig-Smith P. 1983. Quantitative Plant Ecology. Berkley, University of California Press.

JBRJ - Instituto de Pesquisas Jardim Botânico do Rio de Janeiro. 2002. Projeto Tinguá: Paisagem e flora da Reserva Biológica do Tinguá: subsídios ao monitoramento da vegetação. Relatório Técnico-científico. Rio de Janeiro, Instituto de Pesquisas Jardim Botânico do Rio de Janeiro/Universidade Federal Rural do Rio de Janeiro.

Kersten RA, Silva SM. 2001. Composição florística e distribuição espacial de epífitas vasculares em floresta da planície litorânea da Ilha do Mel, Paraná, Brasil. Revista Brasileira de Botânica 24: 213-226.

Kersten RA, Silva SM. 2002. Florística e estrutura do componente epifítico vascular em floresta ombrófila mista aluvial do rio Barigüi, Paraná, Brasil. Revista Brasileira de Botânica 25: 259-267.

Kersten RA, Kuniyoshi S, Roderjan CV. 2009. Epífitas vasculares em duas formações ribeirinhas adjacentes na bacia do rio Iguaçu - Terceiro Planalto Paranaense. Iheringia 64: 33-43.

Kersten RA, Kuniyoshi YS. 2009. Conservação das florestas na bacia do Alto Iguaçu, Paraná - avaliação da comunidade de epífitas vasculares em diferentes estágios serais. Floresta 9: 51-66.

Kersten RA, Waechter JL. 2011. Métodos quantitativos no estudo de comunidades epifíticas. In: Felfili-Fagg JM, Eisenlohr PV, Melo MMRF, Andrade LA, Meira Neto JAA. (eds.). Fitossociologia no Brasil: Métodos e estudos de caso. Viçosa, Ed UFV. p. 231-254.

Medeiros TDS, Jardim MAG. 2011. Distribuição vertical de orquídeas epífitas na Área de Proteção Ambiental (APA) Ilha do Combu, Belém, Pará, Brasil. Revista Brasileira Biociências 9: 3-38.

Mello AC. 2003. Orchidaceae da Ilha de Cabo Frio, município de Arraial do Cabo, RJ. Msc Thesis, Universidade Federal do Rio de Janeiro, Brazil.

Menini Neto L, Válka Alves RJ, Barros F, Forzza RC. 2007. Orchidaceae do Parque Estadual de Ibitipoca, MG, Brasil. Acta Botanica Brasilica 21: 687-696.

Metzger JP. 2000. Tree functional group richness and landscape structure in a Brazilian tropical fragmented landscape. Ecological Applications 10: 1147-1161.

Metzger JP, Martensen AC, Dixo M, et al. 2009. Time-lag in biological responses to landscape changes in a highly dynamic Atlantic forest region. Biological Conservation 142: 1166-1177.

Miller D, Warren R. 1996. Orquídeas do Alto da Serra: da Mata Atlântica Pluvial do sudeste do Brasil. Rio de Janeiro, Lis Gráfica e Ltda.

Miller D, Warren R, Miller IM, Seehawer H. 2006. Serra dos Órgãos: Sua história e suas orquídeas. Nova Friburgo, Scart Editora.

Moreira MM. 2010. Orchidaceae da restinga de Grumari, Rio de Janeiro. Monograph, Universidade Federal do Rio de Janeiro, Brazil.

Nieder J, Prosperí J, Michaloud G. 2001. Epiphytes and their contribution to canopy diversity. Plant Ecology 153: 51-63.

Pabst GFJ, Dungs F. 1975. Orchidaceae Brasilienses. Hildesheim, Kurt Schmersow.

Pereira UZ, Ribeiro LF. 2004. Caracterização de comunidades de Orchidaceae em fragmentos de Floresta Ombrófila Densa Montana, em diferentes estágios de regeneração em Santa Teresa, Espírito Santo, Brasil. Natureza 2: 52-60.

Pielou EC. 1974. Population and Community Ecology: Principles and Methods. New York, Gordon and Breach.

Pinheiro EFM, Pereira MG, Anjos LHC, Machado PLOA. 2004. Fracionamento densimétrico da matéria orgânica do solo sob diferentes sistemas de manejo e cobertura vegetal em Paty do Alferes (RJ). Revista Brasileira de Ciência do Solo 28: 731-737. 
Pinheiro F, Barros F, Lourenço RA. 2004. O que é uma orquídea. In: Barros F, Kerbauy GB. (eds.) Orquidologia sul-americana. São Paulo, Editora do Instituto de Botânica. p. 11-28.

Pinheiro FC. 1999. Orchidaceae do Parque Estadual da Serra da Tiririca. Msc Thesis, Universidade Federal do Rio de Janeiro, Brazil.

Pridgeon AM. 1982. Diagnostic anatomical characters in the Pleurothallidinae (Orchidaceae). American Journal of Botany 69: 921-938.

Ribeiro MC, Metzger JP, Martensen AC, Ponzoni FJ, Hirota MM. 2009. The Brazilian Atlantic Forest: How much is left, and how is the remaining forest distributed? Implications for conservation. Biological Conservation 142: 1141-1153.

Rocha FS, Waechter JL. 2006. Sinopse das Orchidaceae terrestres ocorrentes no litoral norte do Rio Grande do Sul, Brasil. Acta Botanica Brasilica 20: 71-86.

Royer CA. 2013. Filogenia, riqueza, diversidade e endemismo de Phymatidium Lindley (Orchidaceae) e monografia do gênero para o estado do Paraná. Msc Thesis, Universidade Federal do Paraná, Brazil.

Saddi EM, Lopes RC, Andreata RHP. 2005. Floristic and conservation of Orchidaceae at Rio das Pedras Reserve. Selbyana 26: 318-325.

Saddi EM. 2008. Orchidaceae dos Afloramentos Rochosos, Pedra da Gávea, Parque Nacional da Tijuca, Rio de Janeiro. Msc Thesis, Instituto de Pesquisas Jardim Botânico do Rio de Janeiro, Brazil.

Santana IC. 2000. A Família Orchidaceae no Parque Municipal da Taquara, Duque de Caxias, RJ. Msc Thesis, Universidade Federal do Rio de Janeiro, Brazil.
Silva Matos DM, Belinato TA. 2010. Interference of Pteridium arachnoideum (Kaulf.) Maxon. (Dennstaedtiaceae) on the establishment of rainforest trees. Brazilian Journal Biology 70: 311-316.

Thiers B. 2014. Index Herbariorum: A global directory of public herbaria and associated staff. New York Botanical Garden's Virtual Herbarium. http://sweetgum.nybg.org/ih/. 14 Aug. 2014.

Tonhasca Jr A. 2005. Ecologia e história natural da Mata Atlântica. Rio de Janeiro, Interciência.

Veloso HP, Rangel Filho ALR, Lima JCA. 2012. Classificação da vegetação brasileira, adaptada a um sistema universal. Rio de Janeiro, Instituto Brasileiro de Geografia e Estatística.

Viana VM, Pinheiro LAFV. 1998. Conservação da biodiversidade em fragmentos florestais. Série Técnica IPEF 12: 25-42.

Waechter JL. 1986. Epifitos vasculares da Mata Paludosa do Faxinal, Torres, Rio Grande do Sul, Brasil. Iheringia 34: 39-49.

Whitten WM, Williams NH, Dressler RL, Gerlach G, Pupulin F. 2005. Generic relationships of Zygopetalinae (Orchidaceae: Cymbidieae): combined molecular evidence. Lankesteriana 5: 87-107.

Zipparro VB, Guilherme FAG, Almeida-Scabbia RJ, Morellato LPC. 2005. Levantamento Florístico de Floresta Atlântica no sul do Estado de São Paulo, Parque Estadual Intervales, Base Saibadela. Biota Neotropica 5: 147-170.

Zotz G, Hietz P. 2001. The physiological ecology of the vascular epiphytes: current knowledge, open questions. Journal of Experimental Botany 52: 2067-2078. 